\title{
The effect of aqueous extract of Carica papaya leaves on liver enzymes and blood cell counts of normal albino rats
}

\author{
Barine I. NWILOH *, Nwibani M. NWINUKA and Michael O. MONANU \\ Department of Biochemistry, Faculty of science, University of Port Harcourt, \\ PMB 5323, Port Harcourt, Rivers State, Nigeria. \\ *Corresponding author, E-mail: bin4him@yahoo.com; Gsm: (+234) 8037065567.
}

\begin{abstract}
The effects of crude leaf extract of Carica papaya (Linn) on aspartate aminostransferase (AST), alanine aminotransferase (ALT), total white blood cells (WBC), lymphocytes, neutrophils, thrombocytes and on body weight of normal albino rats were investigated. Albino rats weighing between $74 \mathrm{~g}$ and $90.5 \mathrm{~g}$, of both sexes were used for the study. $2 \mathrm{ml}$ of $0.11 \mathrm{~g} / \mathrm{ml}$ aqueous extract was administered daily to each of the experimented rats for the 7 and 14 days study periods respectively, using stomach canula and the parameters analysed using standard methods. Observations indicated that extract of $C$. papaya (Pawpaw) leaves did not induce any significant changes in the levels of AST and ALT. The results also showed that the $C$. papaya leaves extract influenced the immunological pathways. There was an increase in the levels of white blood cells, thrombocytes, lymphocytes and neutrophils of the test rats, and a significant weight gain in the animals at the end of the study period. Based on the findings in this work, the $C$. papaya leaves extract tested could hardly advance any adverse effects on the liver and also have immunological effect on the animal body.

(c) 2009 International Formulae Group. All rights reserved.
\end{abstract}

Keywords: Weight gain, Pawpaw leaves, liver enzymes, blood counts.

\section{INTRODUCTION}

The use of a number of medicinal plants and dietary supplements derived from plants as remedies to some human and animal disease conditions have been very popular for a long time now, (Shanidar, 1975; Gill, 1992; Sofowora, 1993).

In Africa, traditional medicine has been claimed to be vital in preventing and curing various diseases, thereby playing an important role in the health service of the country, especially among the rural dwellers. In Nigeria, people of low-socio economic class depend solely on the use of Carica papaya leaves as remedies to some disease conditions such as malaria, typhoid etc.

Carica papaya (Linn) is one of the economically important fruit trees in the Caricaceae family. The C. papaya (pawpaw) tree is a fast growing tree with alternate leave arrangement. The leaves are palm shaped and dark-green to yellow in colour.

Various parts of $C$. papaya tree including the leaves are used for various medicinal purposes in different parts of the world. In the Niger Delta region of Nigeria, the leaves are used in the treatment of malaria, dysentery, diarrhoea, typhoid etc. It is also used also in the treatment of intestinal parasites. In Ghana, the dried leaf infusion of this plant is taken for stomach troubles as purgative and as abortion inducing concoction (Morton, 1987). According to Agoha (1981), the extract of $C$. papaya leaf is used for the treatment of diseases like asthma, fever, beriberi, rheumatism and also as an antihelminthic.

Also, the antimicrobial activities of $C$. 
papaya leaves have been studied in vitro and reported by Trease and Evans (1989). This research work studies the possible side effect(s) that may result from the constant use of the plant leaf under study, on liver enzymes and blood counts. There are publications in literature on the use of $C$. papaya leaves for medicinal purposes but none has been reported on its side effect or adverse effect in the body. So, this study is designed to investigate the possible side effects of the aqueous extract of $C$. papaya leaves on aspartate aminotransferase (AST), alanine aminotransferase (ALT), total white blood cell (WBC), lymphocyte, neutrophil and thrombocyte levels in the rats, with a view to studying its effect on liver and blood parameters.

\section{MATERIALS AND METHODS Plant material}

Fresh leaves of this plant were harvested from a farm in Nyogor-Beeri, Khana Local Government Area (Ogoni), Rivers State of Nigeria.

The leaves were authenticated at the University of Port Harcourt Herbarium, where a voucher specimen $\left(\mathrm{N}^{\circ} \mathrm{UPH}\right.$ 557) is deposited.

\section{Animals}

Albino rats consisting of 9 males and 11 females, weighing between 74-90.5 g were used for the study. The rats were obtained and maintained at the Animal House of the Department of Biochemistry, University of Port Harcourt. They were housed in wire cages, at room temperature of $29 \pm 1{ }^{\circ} \mathrm{C}$, with a $12 \mathrm{hrs} \mathrm{light/dark} \mathrm{cycle.} \mathrm{The} \mathrm{rats} \mathrm{were} \mathrm{fed} \mathrm{on}$ grower's marsh, clean water ad libitum and aqueous extract of $C$. papaya leaves throughout the duration of the study. Control rats were fed on only grower's marsh and clean water ad libitum.

\section{Weight assessment}

As an index of the physical status of the rats, the weight of each rat was monitored using a compressor spring balance (BAW-660 m) and recorded daily.

\section{Preparation of plant extract}

Fresh leaves of $C$. papaya were cut into pieces and dried in an air circulating corsair heating oven (OVL-350), and allowed to stay overnight. The dried leaves were ground into powder form manually using a mortar and pestle. $50 \mathrm{~g}$ of the resulting powdered materials were soaked in $450 \mathrm{ml}$ of distilled water, using a $500 \mathrm{ml}$ conical flask, stirred carefully for about 8 minutes, corked and then left to stand for about 14 hours. The solution was filtered using filter paper (Whatman $n^{\circ} 1$ ) and the filtrate (extract) stored in a refrigerator at $4{ }^{\circ} \mathrm{C}$ till required for analyses.

\section{Phytochemical Screening}

Chemical tests were carried out using the aqueous leaf extract of $C$. papaya by standard procedures (Trease and Evans 1989, and Sofowora, 1993). Meyer's test was used to detect the presence of alkaloid, while the legal test and the killer-kiliani test, were adopted for cardiac glycosides (Evans, 1997). The ferric chloride test was employed in testing for phenolic compounds, and for tannins the method of Mace-Gorbach (1963) was used. The extract was also tested for presence of anthraquinones, saponins and flavonones using recommended test methods (Wall et al., 1952; Trease and Evans, 1989; Sofowora, 1993; Kokate, 1999).

\section{Design of study groups}

Twenty (20) albino rats divided into two groups of ten (10) rats per group were used for the study.

Group 1 served as the control group, while group 2 consisted of treated rats (rats given the extract).

\section{Administration of leaf extract}

Each of the rats in group 2 received 2 $\mathrm{ml}$ of the extract $(0.11 \mathrm{~g} / \mathrm{ml})$ daily through stomach canula for 7 and 14 days. Rats in the control group received clean water.

\section{Blood sample collection}

At the end of 7 days, five (5) rats from each group were anaesthetized with chloroform and sacrificed by cutting through the jugular vein. The blood pooled from each rat in a group was collected into heparinized bottle for haematological studies. Also part of the blood was collected into another clean bottle (non heparinized) and allowed to clot, for enzyme analyses. The same procedures 
were repeated at the end of the study period (i.e. 14 days).

\section{Determination of white blood cells, thrombocytes and enzymes}

Determination of white blood cells, thombocytes and some white blood differentials were measured using the improved Neubauer counting chamber (Jain, 1986; Dacie and Lewis, 1991). While AST and ALT were estimated using the methods reported by Reitman and Frankel (1957).

\section{Statistical analysis}

The results obtained were analysed by the use of student's t-test (unpaired t-test) for comparison of the results of the extract treated rats to those of the control rats. A 0.05 level of probability was accepted as statistically significant while absolute neutrophil counts (ANC) was used to calculate the neutrophil count as reported by Ayalew-Tefferi (2001).

\section{RESULTS}

The results of the phytochemical screening are shown in table 1. Leaf of $C$. papaya had higher concentration of alkaloid, followed by cardiac glycosides and polyphenol.

The results obtained for the effect of aqueous extract of $C$. papaya leaves on AST and ALT activities are shown in table 2; and the results for its effect on WBC and thrombocytes are shown in table 3. It was observed that aqueous extract of $C$. papaya leaves caused a non significant decrease $(p>0.05)$ in the plasma levels of AST and ALT, of the test rats. Also, administration of the aqueous extract of this plant leaves caused a non significant increase $(p>0.05)$ in total white blood cell and thrombocyte counts.

The results of the study showed a slight increase in the levels of lymphocytes and neutrophils in the test rats (Table 3 ) at the end of the study period. Figure 1 illustrated the pattern of weight changes among the experimented rats. The control group rats that were given only clean water showed a non significant increase in weight of $0.25 \%$ weight gain, while the test rats in group II, which were given the plant leaf extract had a significant increase $(p<0.05)$ in weight of $3.44 \%$ weight gain at the end of the study period (14 days).

\section{DISCUSSION}

Medicinal plant parts have for long been used as source of relief either in the form of traditionally prepared concoctions or in the form of pure active principles. The usefulness of herbs is due to the presence in them of some active ingredients such as alkaloid, volatile oil, tannins etc, similar to those present in orthodox drugs (Dalziel, 1987). Herbs are known to have broad actions on a number of physiological systems in the body and it is a general feeling in the community that they rarely have any adverse effect (Treasure, 2000).

The presence of phytochemical constituents in medicinal plant parts have been reported (Trease and Evans, 1989; Sofowora, 1993; Evans, 1997). The leaf of $C$. papaya contained alkaloids and cardiac glycosides among others phytochemmicals, which are of great pharmacological importance. Similar results with the leaves of C. papaya have been reported by Ekpe et al. (1990).

Table 1: Phytochemical components of aqueous extract of $C$. papaya leaves.

\begin{tabular}{lc}
\hline Phytochemicals & Components present \\
\hline Tannins & + \\
Cardiac glycosides & ++ \\
Alkaloids & +++ \\
Saponins & + \\
Anthraquinones & + \\
Flavonoids & + \\
Polyphenols & ++ \\
\hline +: presence of component tested; & $-:$ absence of component tested.
\end{tabular}


Table 2: The effects of aqueous extract of C. papaya on the enzymes.

\begin{tabular}{lccc}
\hline Group & Days & AST (U/l) & ALT (U/l) \\
\hline \multirow{2}{*}{ I } & 7 & $24.07 \pm 2.82$ & $41.57 \pm 3.21$ \\
& 14 & $24.05 \pm 4.80$ & $41.00 \pm 3.00$ \\
\hline \multirow{2}{*}{ II } & 7 & $20.62 \pm 1.15$ & $36.02 \pm 3.74$ \\
& 14 & $20.93 \pm 5.24$ & $35.56 \pm 7.61$ \\
\hline \multicolumn{4}{r}{} \\
$=5$; AST: aspartate aminotransferase; ALT: alanine aminotransferase
\end{tabular}

Table 3: The effects of aqueous extract of $C$. papaya on WBC, lymphhocytes, neutrophils and thrombocytes.

\begin{tabular}{|c|c|c|c|c|c|}
\hline Group & Days & $\begin{array}{c}\text { WBC } \\
(\mathbf{x 1 0} / 1)\end{array}$ & $\begin{array}{c}\text { Lymphocytes } \\
(\%)\end{array}$ & $\begin{array}{l}\text { Neutrophils } \\
\left(\times 10^{6} / \mu \mathrm{l}\right)\end{array}$ & $\begin{array}{c}\text { Thrombocytes } \\
\left(\mathbf{x 1 0} / \mathbf{m m}^{3}\right)\end{array}$ \\
\hline \multirow[b]{2}{*}{ I } & 7 & $2.50 \pm 0.3$ & $58.1 \pm 4.34$ & $1.025 \pm 7.06$ & $1.20 \pm 0.37$ \\
\hline & 14 & $2.60 \pm 1.7$ & $59.0 \pm 0.00$ & $1.0608 \pm 0.02$ & $1.22 \pm 0.00$ \\
\hline \multirow{2}{*}{ II } & 7 & $3.00 \pm 1.7$ & $64.4 \pm 63.62$ & $1.041 \pm 9.12$ & $1.35 \pm 0.46$ \\
\hline & 14 & $3.90 \pm 1.1$ & $69.7 \pm 4.40$ & $1.1973 \pm 11.2$ & $1.90 \pm 0.18$ \\
\hline
\end{tabular}

$\mathrm{n}=5 ;$ WBC: white blood cell

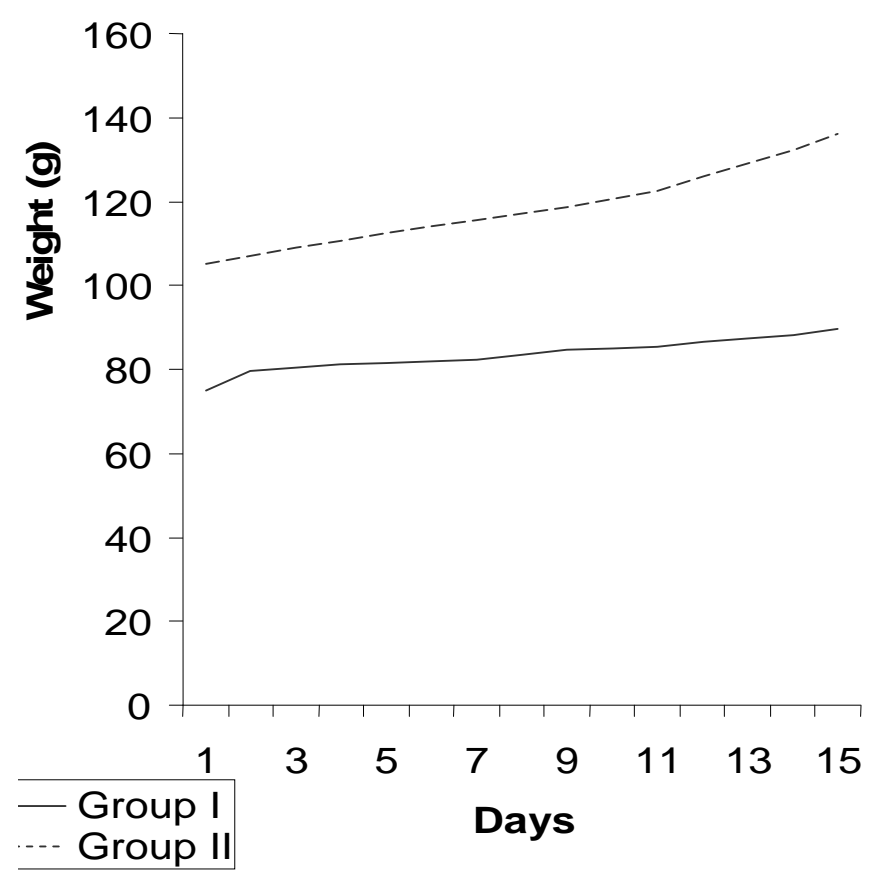

Figure 1: Changes in mean body weights of rats given $C$. papaya extract. $\mathrm{n}=10$. 
Drugs like quinine and morphine containing alkaloids and cardiac glycosides are very useful for the treatment of dropsy, high blood pressure and other diseases related to malfunctioning of the heart (Ross and Brain, 1977). The phytochemical components could be exploited for use in the production of drugs and other medicinal products.

The results obtained in this study showed that the aqueous extract of $C$. papaya leaves caused a non significant increase in the levels of AST and ALT. Any elevation in the levels of AST and ALT above the normal ranges (that of the control) could be associated with cell necrosis of many tissues in the body, such as myocardial infarction, liver disorder, toxic jaundice, etc (Singh, 2004). This is because pathology involving tissues such as liver, cardiac or skeletal muscles, allows for the leakage of large amounts of these enzymes into the blood (Kaneko, 1980). This will in turn raise the levels of these liver function enzymes in the blood plasma. On the other hand, ALT is present in enclosed compartments of the liver and in other cells, and they are particularly useful in measuring hepatic necrosis, especially in small animals (Cornelius, 1989). Since ALT is one of the specific assayable liver marker enzymes, its non-elevated level in this study is an indication of no hepatic damage caused by the administration of the crude plant leaf extract under study.

The effect of the extract of C. papaya leaves on white blood cells, thrombocytes, lymphocytes and neutrophils are attributed to their influences on the haemopoietic system of the rats. This argument is supported by slight increases in WBC, thrombocytes, and lymphocytes following administration of the plant leaf extract under study to the rats. Similar observations have been reported by others working with different plant parts (Adisa et al., 1999; Muyibi et al., 2000; Nwinuka et al., 2008). Values of thrombocytes were in normal ranges, an indication of no injury caused by the plant leaf extract under study.

The observed non significant increase in the levels of lymphocytes with a corresponding increase in the level of neutrophils may implicate immunological pathways (Okochi et al., 2003). The positive effect of aqueous extract of $C$. papaya leaves can be deduced also from the weight status of the experimented rats (figure 1). The extract significantly increased $(\mathrm{p}<0.05)$ the weights of the test rats. Similar observations have been reported by Nwinuka et al. (2008). This observation is an indication of the fact that the rats were in a better physical state. This study then showed that aqueous extract of $C$. papaya leaves did not impose any acute fluid loss, proteolysis and lipolysis in the test rats, and as a result, have no adverse effect(s) on their body weights (Albert and Zimmet, 1998).

In conclusion, the administration of the aqueous extract of $C$. papaya leaves to rats results in weight gain and has no effect on liver enzymes; hence it is expected to be non toxic to the liver. It also results in slight changes in pattern of WBC distribution, which might be due to the immunological effects of the drug.

\section{ACKNOWLEDGEMENTS}

The authors gratefully acknowledge the assistance of the management of Chief Peter U. Nwiloh farm, for the collection of the plant leaves.

\section{REFERENCES}

Adisa OA, Ajayi OA, Awujo NC, Thomas BN. 1999. Haematolobiochemical changes in albino rats infected with $T$. brucei. Nig. Quart. J. Hosp. Med., 9: 238-240.

Agoha RC. 1981. Medical plants of Nigeria. Offset Drukkeriji Faculted Der Wiskunde en Natuorwetens, chappens, Nijimegen, Netherland.

Albert KGMM, Zimmet PZ. 1998. Definition, diagnosis and classification of diabetes mellitus and its complication part 1 : disguises and classification of diabetes mellitus provisional report of WHO consultations. Diabet Med., 15: 539-553.

Ayalew-Tefferi MD. 2001. Primary Hematology. Totowa NJ (ed). Humana Press.

Cornelius CE. 1989. Clinical Biochemistry of Domestic Animals: Serum Enzyme Activities and Other Markers for Detecting Hepatic Necrosis, Cholestasis or Co-carcinoma $\left(4^{\text {th }}\right.$ edn). Academy Press. 
Dacie JV, Lewis SM, 1991. Practical Haematology $\left(7^{\text {th }}\right.$ edn). ELBS with Churchil Livingstone: England.

Dalziel JM 1987. The Useful Plants of Tropical West Africa. Grown Agents; 6669.

Ekpe ED, Ebanna RUB, Madunagu BE. 1990. Antimicrobial activity of four medicinal plants on pathogenic bacteria and phytopathogenic fungi. W. Afr. J. Biol Applied. Chem., 35(1-4): 2-5.

Evans WC. 1997. An index of medicinal plants. Pharmacognosy, 7(5): 12-14.

Farnsworth NR, Akerele O, Bingel AS, Soejarto DD, Guo ZG. 1985. Medicinal plants in therapy. Bull. of the WHO, 63: 965-981.

French S, Kochhar A. 2004. Essential haematology. Student BMJ., 12: 393-436.

Gill LS. 1992. Ethnomedical Used of Plants in Nigeria. Uniben Press: Benin City.

Jain NC. 1986. Schalm's Veternary Haematology $\left(14^{\text {th }}\right.$ edn). Lea and Fabiger: Philadelphia.

Kaneko JJ. 1980. Clinical Biochemistry of Domestic Animals ( $3^{\text {rd }}$ edn). American Press: Orlando.

Kokate A. 1999. Phytochemical methods. Phytother, 78: 126.

Mace-Gorbach SL. 1963. Anaerobic bacteriology for clinical laboratories. Pharmacognosy, 23: 69.

Morton J. 1987. Post operation of pawpaw. In Tamarid Fruit of Warm Climates. Creative Resources System Inc: Miami FL, USA.

Muyibi SA, Olorode BR, Onyeyili PA, Osunkwo UA, Mohammed BY, Ajagbonna OP. 2000. Haematological and histopathological changes of Ucassia occidentalis leaf extract in rats. Nig. J. Nat. Prod. Med., 4: 48-52.

Nwinuka NM, Monanu MO, Nwiloh BI. 2008. Effect of Aqueous Extract of $M$. indica Stem Bark on Haematological Parameters of Normal Albino Rats. Pak. J. Nutri., 7(5): 663-666.

Okochi VI, Okpuzor J, Okubena MO, Awoyemi AK. 2003. The influence of African Herbal formula on the haematological parameters of trypanosome infected rats. Afr. J. Biotechnol., 2(9): 312-316.

Reitman S, Frankel S. 1957. Principle of AST method of Measurement. Am. J. Clin. Pathology, 32: 97.

Ross MST, Brain KR. 1977. An Introduction to Phytopharmacy. Pitman Medical Publishing Coy: Tunbridge Well, Kent.

Singh SP. 2004. Practical Manual of Biochemistry $\left(5^{\text {th }}\right.$ edn). CBS publisher and Distributor: New Delhi.

Shanidar IVSR. 1975. A Neanderthal Flower Burial in northern Iraq. Sci., 190: 880.

Sofowora A. 1993. Medical Plants and Traditional Medicines in Africa. Chichester John, Willey and Sons: New York.

Trease GE, Evans WC. 1989. A Textbook of Pharmacognosy $\left(13^{\text {th }}\right.$ edn). Bailliere Tindall: London.

Treasure J. 2000. Medical herb. (Online). http://www.herbiological.com.

Wall ME, Eddy CR, McClenna ML, Klump ME. 1952. Detection and estimation of steroid and sapogenins in plant tissues. Analytical Chem., 24: 1337. 